\title{
Nitrogen cycling, retention and export in a eutrophic temperate macrotidal estuary
}

\author{
Natacha Brion ${ }^{1, *}$, Maria G. I. Andersson ${ }^{2}$, Marc Elskens ${ }^{1}$, Cristina Diaconu ${ }^{1}$, \\ Willy Baeyens ${ }^{1}$, Frank Dehairs ${ }^{1}$, Jack J. Middelburg ${ }^{2}$ \\ ${ }^{1}$ Department of Analytical and Environmental Chemistry, Vrije Universiteit Brussel, Pleinlaan 2, 1050 Brussels, Belgium \\ ${ }^{2}$ Netherlands Institute of Ecology (NIOO-KNAW), Centre for Estuarine and Marine Ecology, Korringaweg 7, \\ 4400 NT Yerseke, The Netherlands
}

\begin{abstract}
The ecological functioning of estuarine environments is greatly influenced by human activity. One of the most important perturbations lies in the increased inputs of nutrients, mainly nitrogen $(\mathrm{N})$, to these systems. This $\mathrm{N}$ is submitted to various biogeochemical processes leading to recycling, retention and export to the sea. In this article we present results from ${ }^{15} \mathrm{~N}$-incubation experiments allowing the simultaneous determination of $\mathrm{NH}_{4}{ }^{+}$and $\mathrm{NO}_{3}{ }^{-}$uptake, nitrification and ammonification rates in the waters of a eutrophic temperate macrotidal estuary (the Scheldt in Belgium and The Netherlands) for different seasons. These are compared to whole estuarine nitrogen budgets. Results showed that nitrogen cycling in this system is dominated in all seasons by the mineralization of organic matter leading to a supply of dissolved inorganic nitrogen (DIN) exceeding river inputs. During winter, summer and fall seasons, only 6 to $10 \%$ of this DIN is recycled by microorganisms and most is eliminated (50 to $60 \%$ ), probably by denitrification in the sediments, and exported (30 to $40 \%$ ) to the sea. In spring, a larger fraction of DIN (around $70 \%$ ) is recycled by microorganisms, while only $2 \%$ is eliminated and $26 \%$ is exported. Overall, we conclude that turbid eutrophic temperate estuaries as the Scheldt may have low DIN recycling efficiencies because of low in situ primary production except in spring.
\end{abstract}

KEY WORDS: Nitrogen budget $\cdot{ }^{15} \mathrm{~N}$ incubation $\cdot$ Nitrification $\cdot$ Ammonification $\cdot \mathrm{NH}_{4}{ }^{+}$uptake $\mathrm{NO}_{3}{ }^{-}$uptake $\cdot$ Estuaries

\section{INTRODUCTION}

Estuaries are important transition zones between freshwater and marine ecosystems. They are subject to major chemical, biological and physical gradients and concentrate, over relatively small areas, the influence of large watershed surfaces. Because of their location at the interface between land and sea, they often represent important economic regions with high population densities. Human pressure on these environments is thus very large and, consequently, perturbation of the natural functioning of these systems is extreme. One of the most important perturbations lies in the increased inputs of nutrients (mainly nitrogen and phosphorus) to rivers. In particular, nitrogen loads, linked to human activities and population growth, have increased dramatically over the past century (e.g. Hulth et al. 2005).

A large fraction of the nitrogen delivered to estuaries is removed primarily by nitrogen gas formation by denitrification and anammox (anaerobic ammonium oxidation), and by burial of organic nitrogen in sediments (Heip et al. 1995). This nitrogen removal has major consequences for the transfer of riverine nitrogen to the sea and the functioning and eventual eutrophication of downstream coastal ecosystems. The important self-purification role of estuaries regarding the nitrogen loads has been well documented by whole ecosystem nitrogen budget studies, and it has been shown that the estuarine filter function depends 
mainly on the water residence time (e.g. Seitzinger et al. 2006). However, these studies often do not distinguish nitrogen species (organic nitrogen [orgN], $\mathrm{NH}_{4}{ }^{+}$, $\mathrm{NO}_{3}{ }^{-}$), nor do they provide information on how this estuarine filter function responds to changes in nutrient loadings or riverine discharge. For instance, shortening residence time because of enhanced river discharge might cause less retention with consequences for coastal ecosystem functioning. Additionally, recent retrospective analysis has shown that the estuarine filter function is subject to change as well (Soetaert et al. 2006), complicating any predictive study of coastal ecosystem response to enhanced or reduced anthropogenic nitrogen loading. It is therefore imperative to unravel within-estuarine recycling processes such as orgN mineralization to $\mathrm{NH}_{4}{ }^{+}$(ammonification), uptake and assimilation of dissolved inorganic nitrogen (DIN = $\mathrm{NH}_{4}{ }^{+}$and $\mathrm{NO}_{3}{ }^{-}$), nitrification and nitrogen exchanges with the sediments and lateral ecosystems such as tidal marshes.

Some studies report DIN uptake by pelagic microbes in estuaries (e.g. Andersson et al. 2006b), ammonification (e.g. Miller et al. 1995) or nitrification rates (e.g. Andersson et al. 2006a), but there are very few estuarine systems (Lipshultz et al. 1986) where all these processes have been measured during the same period and in a systematic, consistent way. These studies indicate that processes are of similar magnitude but might exhibit differential seasonality. The coupling between regeneration (ammonification and nitrification) and assimilation processes indicates that nitrogen cycling is intense and that each nitrogen molecule may be recycled many times before it is trans-

ferred to the sea.

The objectives of this paper are to (1) present results from ${ }^{15} \mathrm{~N}$-incubation experiments allowing the simultaneous determination of pelagic $\mathrm{NH}_{4}{ }^{+}$and $\mathrm{NO}_{3}{ }^{-}$uptake, nitrification and ammonification rates in the waters of a macrotidal estuary for different seasons; and (2) derive a whole estuarine nitrogen budget for the same periods. When considered within the overall estuarine nitrogen cycle, these internal nitrogen cycling processes will allow a better understanding of how the estuarine nitrogen filter will function under changing conditions. Moreover, we will report both (1) the relative contribution of various nitrogen cycling processes to estuarine retention, and (2) estimates for nitrogen recycling efficiencies, by considering the number of times a nitrogen-containing molecule cycles while transiting through the estuary. This can then be considered in a global perspective by comparison to recycling numbers in streams (Ensign \& Doyle 2006).

\section{MATERIALS AND METHODS}

Study site: the Scheldt estuary. With an average population density of 425 ind. $\mathrm{km}^{-2}$ in its watershed, the estuary of the Scheldt River (Belgium and The Netherlands, Fig. 1) represents a characteristic case of a large temperate macrotidal estuary under the influence of human activities. The studied section of the estuary is limited upstream by the maximum salt intrusion (around the confluence with the Rupel River). The Scheldt estuary is a broad (from $\sim 500 \mathrm{~m}$ near Antwerp to $\sim 6 \mathrm{~km}$ near Vlissingen), relatively shallow (10 m mean depth), and rather short $(100 \mathrm{~km})$ funnel shaped macrotidal estuary with a medium average freshwater discharge of $104 \mathrm{~m}^{3} \mathrm{~s}^{-1}$ and a sigmoidal type salinity gradient covering a distance between 80 and $100 \mathrm{~km}$ (Soetaert et al. 2006) according to tide coefficient and freshwater flow rates. Twenty-five percent of the area of the estuary is covered by large intertidal flats (Kromkamp et al. 1995). Its hydrology has been largely described by Baeyens et al. (1998). The water column is homogenous for dissolved species but strong gradients are displayed for particulate matter due to re-suspension and reworking of bottom sediment by tidal currents (Chen et al. 2005).

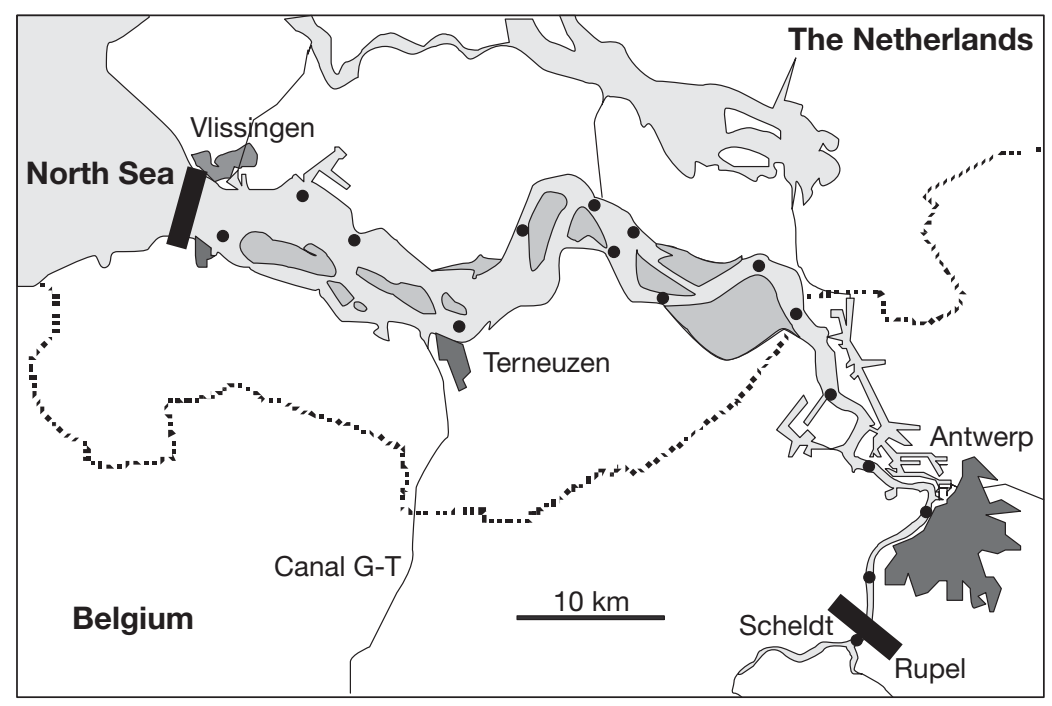

Fig. 1. The Scheldt estuary. (•) Fixed sampling stations; medium-grey areas: shallow areas or intertidal mud flats; Canal G-T: Ghent-Terneuzen canal; dashed line: Belgian-Dutch border; black bars: up- and down-stream limits (Rupelmonde and Breskens respectively) of the estuary considered for budgeting purposes 
Nitrogen budgets have been studied in detail for the 1970s (Billen et al. 1985), the 1980s (Soetaert \& Herman 1995), 1995 (Regnier \& Steefel 1999), and finally for the 1970s to the early 2000s (Soetaert et al. 2006). These studies documented that the Scheldt estuary has been subject to large changes since the 1970s. Indeed, gradual implementation of wastewater purification plants in the upstream basins was responsible for the restoration of water-column oxygen concentrations. In the 1970s, a large part of the estuary was subjected to anoxic conditions during most of the year while in the 1990s and 2000s, low oxygen conditions only lasted for a few days during warm low river water discharge conditions (Soetaert et al. 2006). Accordingly, because of higher water column oxygen levels, for similar hydrological conditions, the amount of $\mathrm{N}$ removed during transport to the sea decreased from $40-50 \%$ of inputs in the 1970 s (Billen et al. 1985) to $20 \%$ in the 1990s (Soetaert et al. 2006).

Sampling. Surface (2 $\mathrm{m}$ depth) water samples were collected with a $20 \mathrm{l}$ Niskin bottle from a ship (RV 'Luctor') during $4 \mathrm{~d}$ cruises in January, April, July and October 2003. For each cruise, 16 fixed-location (Fig. 1) and 4 fixed-salinity $(2,4,18$ and 28) stations were sampled for respectively DIN and orgN determinations and incubation experiments with ${ }^{15} \mathrm{~N}$ tracers. All water samples were immediately processed on board after retrieval. Temperature and salinity were recorded at all stations using specific probes and freshwater discharges were 195, 80, 90 and $51 \mathrm{~m}^{3} \mathrm{~s}^{-1}$ for the sampling periods of January, April, July and October, respectively.

Concentration measurements. Methodologies for the estimation of $\mathrm{NH}_{4}{ }^{+}, \mathrm{NO}_{3}{ }^{-}$(represents nitrate + nitrite throughout this article), and particulate organic nitrogen (PON) concentration are described in Andersson et al. (2006a). Total dissolved nitrogen (TDN) was measured as $\mathrm{NO}_{3}{ }^{-}$with a persulfate digestionoxidation method (Dafner et al. 1999). Digestion occurred in $50 \mathrm{ml}$ Teflon sample vessels in a microwave sample preparation system (CEM, model Mars 5) for $2 \mathrm{~h}$ at $600 \mathrm{~W}$ with temperatures and pressures ranging from ambient to a maximum of $170^{\circ} \mathrm{C}$ and 100 psi. Finally, $\mathrm{NO}_{3}{ }^{-}$was measured after reduction on a cadmium column with an automated colorimetric method using a Technicon auto-analyzer 2 (Strickland \& Parsons 1972). Dissolved organic nitrogen (DON) was computed by subtracting $\mathrm{NH}_{4}{ }^{+}$and $\mathrm{NO}_{3}{ }^{-}$concentrations from TDN measurements. The relative standard deviation on laboratory replicate measurements was $2,2,5$ and $10 \%$ for $\mathrm{NH}_{4}{ }^{+}, \mathrm{NO}_{3}{ }^{-}, \mathrm{PON}$ and $\mathrm{DON}$ respectively.

Incubation experiments. Isotope dilution and enrichment incubation experiments were performed using ${ }^{15} \mathrm{~N}$-labelled DIN $\left(\mathrm{NH}_{4}{ }^{+}\right.$or $\left.\mathrm{NO}_{3}{ }^{-}\right)$. For these experiments, we used seven $250 \mathrm{ml}$ aliquots of the water samples in transparent plastic polycarbonate bottles submerged in an open deck incubator with continuously flowing water to ensure ambient temperature and light intensities. For each sample, 3 parallel incubation series were performed. In the first series of incubations, aliquots were spiked with ${ }^{15} \mathrm{~N}_{-} \mathrm{NH}_{4}{ }^{+}$ (between 2 and $10 \%$ final ${ }^{15} \mathrm{~N}$ abundance), incubated for 2 or $6 \mathrm{~h}$, and filtered on combusted GF/F glass-fiber filters (Whatman). The filters were dried at $50^{\circ} \mathrm{C}$ for $8 \mathrm{~h}$ prior to analysis of PON and ${ }^{15} \mathrm{~N}-\mathrm{PON}$ abundance. Additionally, for the aliquots incubated for $6 \mathrm{~h}$, the filtrate was frozen until analysis of final $\mathrm{NH}_{4}{ }^{+}$concentration (Koroleff 1969) and ${ }^{15} \mathrm{~N}^{-\mathrm{NH}_{4}}{ }^{+}$abundance (Diaconu et al. 2005). In the second series, aliquots were spiked with ${ }^{15} \mathrm{~N}-\mathrm{NH}_{4}{ }^{+}$(between 2 and $10 \%$ final ${ }^{15} \mathrm{~N}$ abundance), incubated for approximately 3,6 , or $9 \mathrm{~h}$ and filtered on combusted GF/F filters (Whatman). The filtrate was frozen until analysis for the final ${ }^{15} \mathrm{~N}_{-} \mathrm{NH}_{4}{ }^{+}$ and ${ }^{15} \mathrm{~N}^{-\mathrm{NO}_{3}}{ }^{-}$(Andersson et al. 2006a). Finally, in the last series, aliquots were spiked with ${ }^{15} \mathrm{~N}_{-} \mathrm{NO}_{3}{ }^{-}$ (between 2 and $5 \%$ final ${ }^{15} \mathrm{~N}$ abundance), incubated for 2 or $6 \mathrm{~h}$, and filtered on combusted GF/F membranes (Whatman). The filters were dried at $50^{\circ} \mathrm{C}$ for $8 \mathrm{~h}$ prior to analysis of PON and ${ }^{15} \mathrm{~N}-\mathrm{PON}$ abundance. Additionally, for the aliquots incubated for $6 \mathrm{~h}$, the filtrate was frozen until analysis of final $\mathrm{NO}_{3}{ }^{-}$concentration (Strickland \& Parsons 1972).

In all cases, ${ }^{15} \mathrm{~N}$ abundances and PON concentration were measured using an elemental analyzer (CarloErba $\mathrm{C} / \mathrm{N}$ analyzer) coupled via a conflo-interface to an isotope ratio mass spectrometer (Finnigan DeltaPlus XL) (Nieuwenhuize et al. 1994). The relative standard deviation on replicate ${ }^{15} \mathrm{~N}$ measurements was less than $5 \%$.

Initial and final ${ }^{15} \mathrm{~N}$-abundance and concentration data for the $\mathrm{NH}_{4}{ }^{+}, \mathrm{NO}_{3}{ }^{-}$and PON pools obtained from the 3 incubation experiments were used simultaneously in an isotopic mass-balance model in order to compute $\mathrm{NH}_{4}{ }^{+}$and $\mathrm{NO}_{3}{ }^{-}$uptake rates, nitrification rates and ammonification rates. The model is a 3 compartment open model allowing the assessment of exchange rates between the considered compartments: $\mathrm{NH}_{4}{ }^{+}, \mathrm{NO}_{3}{ }^{-}$and PON. This model assumes that exchange between compartments is governed by first order differential equations with constant coefficients of the general type:

$$
\frac{\mathrm{d}^{p} X_{i}}{\mathrm{~d} t}=\sum_{j \neq i}^{n} k_{j i} \cdot{ }^{p} X_{j}-\sum_{j \neq i}^{n} k_{i j} \cdot{ }^{p} X_{i}
$$

where $X_{i}$ is the nitrogen concentration of isotope $p\left({ }^{14} \mathrm{~N}\right.$ or ${ }^{15} \mathrm{~N}$ ) within compartment $i$ at time $t, k_{i j}$ is the rate constant for exchange from compartment $i$ to compartment $j$ (in reciprocal time units) and $n$ represents the 
number of compartments (3 in this case: $\mathrm{NH}_{4}{ }^{+}, \mathrm{NO}_{3}{ }^{-}$ and PON).

The equation above states that the net content in any compartment $i$ equals the sum of all inflows from the other compartments minus the sum of all outflows towards the other compartments. These mass balance differential equations have been solved numerically as described in Elskens et al. (1988). Values for the rate constants were obtained using weighted least squares techniques as described in Elskens et al. (2005). Rates for initial conditions were then obtained by multiplying rate constants with the in situ concentrations of $\mathrm{NH}_{4}^{+}$or $\mathrm{NO}_{3}{ }^{-}$.

Nitrogen budget for the Scheldt estuary. Inputs of $\mathrm{N}$ by the Scheldt River and tributaries, as well as output of $\mathrm{N}$ to the sea, were calculated for the 4 major forms of $\mathrm{N}: \mathrm{NH}_{4}{ }^{+}, \mathrm{NO}_{3}{ }^{-}, \mathrm{PON}$ and DON.

Input from the Scheldt River and output to the sea: The water column of the Scheldt River is well mixed with regard to dissolved species. Daily inputs of dissolved $\mathrm{N}$ by the Scheldt River upstream were calculated by multiplying the daily freshwater discharge with the concentration measured at Rupelmonde, just after the confluence of the Scheldt with the Rupel River (Fig. 1). At this station, salinity (0.4, 0.5, 1.0 and 0.9 for January, April, July and October, respectively) showed only a limited marine influence. Daily outputs of dissolved $N$ to the sea were estimated from the calculation of the 'effective zero salinity end-member concentration' (Officer 1979). This method is based on the assumption that the estuary is in steady state and there is a chemical continuity between the river and the sea water, or, that mixing processes in estuaries and freshwater plumes are chemically conservative. Practically, the effective concentration that reaches the marine endmember is determined by fitting a linear regression line through the data points in the high-salinity region of the estuary. Extrapolation of the regression lines to salinity 0 allows the calculation of the freshwater end-member concentrations, while multiplication by the daily freshwater discharge at the mouth allows estimation of the daily output of dissolved nitrogen from the estuary.

Daily inputs and outputs of PON were estimated using the same methods, although measured surface PON may not be representative of the whole water column (Chen et al. 2005). Estimated inputs and outputs are thus minimum estimates only taking into account surface suspended particulate matter (SPM). PON associated with SPM from bottom waters, mainly originating from sediment re-suspension (Chen et al. 2005), was thus not taken into account in our estimates.

Lateral inputs: Between Rupelmonde and Breskens, the estuary receives several effluents from canals, mainly the Ghent-Terneuzen canal, and cities, mainly the Antwerp agglomeration and its harbor (940700 inhabitants in January 2003 according to the National Institute of Statistics, Belgium; www.statbel.fgov.be/figures/d21_fr.asp\#2). These effluents contribute $\sim 30 \%$ (20\% from canals and 10\% from the city and harbor; Soetaert et al. 2006) to the freshwater discharge at the mouth of the estuary, and are also $\mathrm{N}$ sources. The contribution of the canals to the $\mathrm{N}$ inputs was roughly estimated using mean annual concentrations of $\mathrm{NH}_{4}{ }^{+}, \mathrm{NO}_{3}{ }^{-}$and total nitrogen for the Ghent-Terneuzen canal and for several other smaller canals and polder effluents given in the OSPAR (Oslo and Paris Commissions) reports (OSPAR Commission 2005). These concentrations were $52 \mu \mathrm{mol} \mathrm{NH}_{4}^{+} \mathrm{l}^{-1}, 436 \mu \mathrm{mol} \mathrm{NO}_{3}^{-} \mathrm{l}^{-1}$ and $116 \mu \mathrm{mol} \operatorname{orgN~~^{-1}}$ in 2003. Mean concentrations were multiplied by the water discharge calculated as $20 \%$ of the freshwater discharge at the mouth of the estuary (Soetaert et al. 2006).

The contribution of the Antwerp agglomeration was estimated as a function of the population (940700 inhabitants) and taking into account that in 2003, $90 \%$ of the produced sewage was treated with a secondary treatment technology leaving $10 \%$ untreated (AQUAFIN pers. comm.). The associated $\mathrm{NH}_{4}{ }^{+}, \mathrm{NO}_{3}{ }^{-}$, DON and PON loads were estimated using specific loads per inhabitant (inh.) determined for the Paris agglomeration (France; Servais et al. 1999) which can be considered as typical for large West-European cities. These were for treated sewage: $9.0 \mathrm{~g} \mathrm{~N}^{-\mathrm{NH}_{4}}{ }^{+}$ inh. ${ }^{-1} \mathrm{~d}^{-1}, 0.1 \mathrm{~g} \mathrm{~N}^{-\mathrm{NO}_{3}}{ }^{-}$inh. $^{-1} \mathrm{~d}^{-1}$ and $1.95 \mathrm{~g}$ orgN inh. ${ }^{-1}$ $\mathrm{d}^{-1}$; and for untreated sewage: $8.8 \mathrm{~g} \mathrm{~N}-\mathrm{NH}_{4}{ }^{+} \mathrm{inh}^{-1} \mathrm{~d}^{-1}$, $0.17 \mathrm{~g} \mathrm{~N}^{-\mathrm{NO}_{3}}{ }^{-} \mathrm{inh}^{-1} \mathrm{~d}^{-1}$, and $3.97 \mathrm{~g}$ orgN inh. ${ }^{-1} \mathrm{~d}^{-1}$ (Servais et al. 1999).

\section{RESULTS}

\section{Longitudinal profiles}

The temperature, $\mathrm{NH}_{4}{ }^{+}$and $\mathrm{NO}_{3}{ }^{-}$profiles have already been reported by Andersson et al. (2006a) and thus they are only briefly discussed here. Water temperature varied with season averaging 4, 10, 20 and $14^{\circ} \mathrm{C}$ in January, April, July and October, respectively. $\mathrm{NH}_{4}{ }^{+}$concentrations (Fig. 2) were highest in the freshwater section of the estuary $(\leq 150 \mu \mathrm{M})$ and decreased with increasing salinity. $\mathrm{NO}_{3}{ }^{-}$concentrations (Fig. 2) in the freshwater section were around $300 \mu \mathrm{mol} \mathrm{l}^{-1}$. They increased or were uniform until salinity reached $\sim 10$, and from there decreased throughout the estuary. PON (Fig. 2) was the least abundant $\mathrm{N}$ form in surface waters of the Scheldt with highest concentrations in the freshwater part 


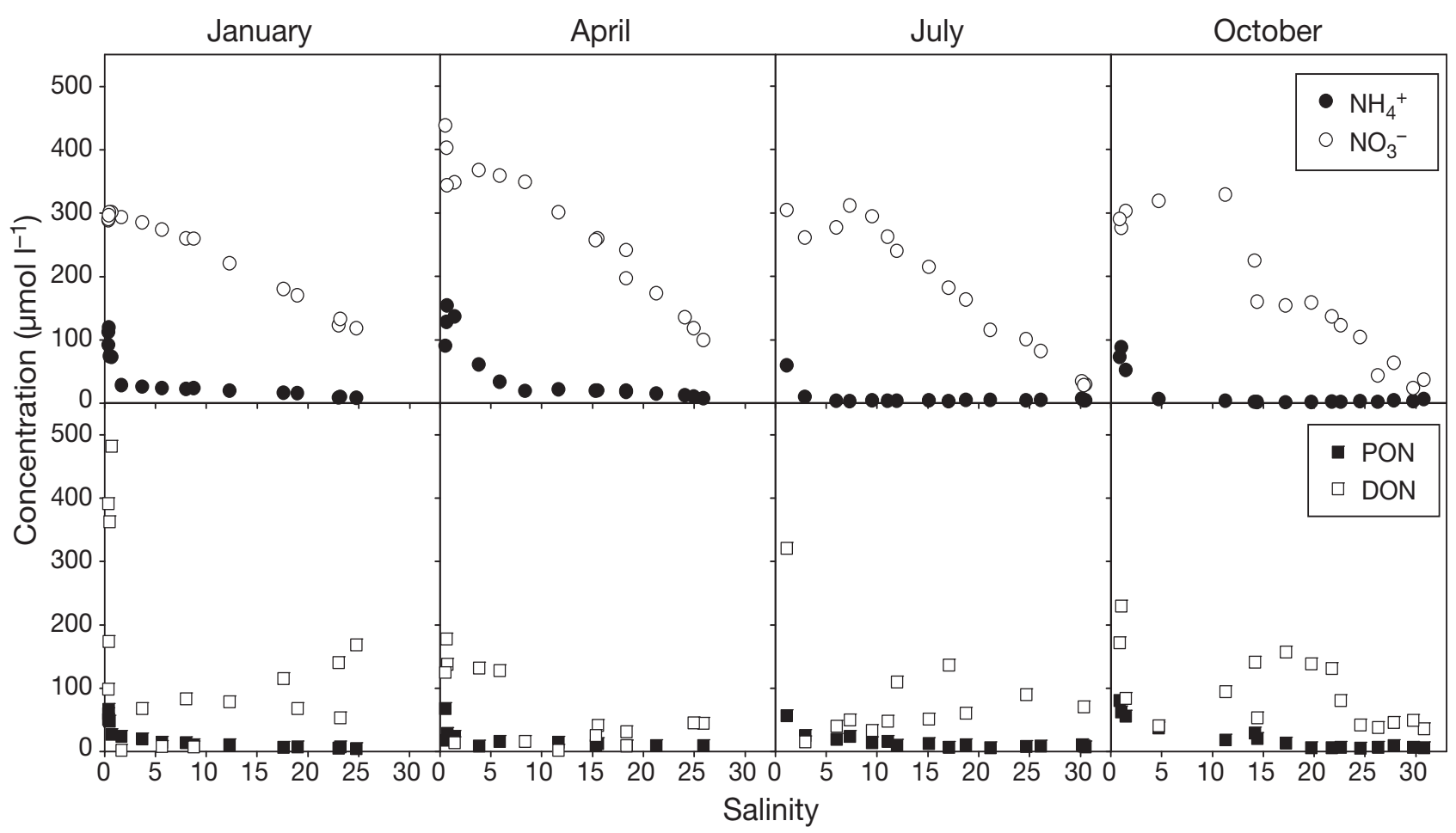

Fig. 2. Longitudinal profiles of ammonium $\left(\mathrm{NH}_{4}{ }^{+}\right)$, nitrate + nitrite $\left(\mathrm{NO}_{3}{ }^{-}\right)$, dissolved organic nitrogen (DON) and particulate organic nitrogen (PON) in the Scheldt estuary in January, April, July and October 2003

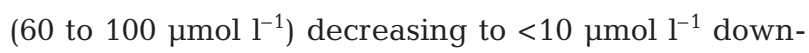
stream. DON (Fig. 2) displayed high concentrations in the freshwater part (120 to $\left.390 \mu \mathrm{mol} \mathrm{l}^{-1}\right)$ with levels comparable to those of $\mathrm{NO}_{3}^{-}$in some cases. Downstream, DON generally decreased rapidly until salinity reached 10 . In July and October, there was a small increase in DON around salinities of 15 to 20 before a general decrease at the mouth of the estuary.

\section{Pelagic $\mathbf{N}$ transformation rates}

$\mathrm{NH}_{4}{ }^{+}$and $\mathrm{NO}_{3}{ }^{-}$uptake and regeneration (ammonification, nitrification) rates are presented in Fig. 3. Uptake rates were highest in April (spring) and especially for $\mathrm{NH}_{4}^{+}$in the upper estuary (up to $2 \mu \mathrm{mol} \mathrm{l}^{-1}$ $\mathrm{h}^{-1}$ ). Nitrification rates were highest in April and October (up to $0.6 \mu \mathrm{mol} \mathrm{l}^{-1} \mathrm{~h}^{-1}$ ) and generally decreased with increasing salinity. Ammonification rates were highest in January and October (up to $0.3 \mu \mathrm{mol} \mathrm{l}^{-1} \mathrm{~h}^{-1}$ ). Ammonification, nitrification and ammonium uptake contributed significantly to estuarine nitrogen transformations and could each dominate during certain periods. $\mathrm{NO}_{3}^{-}$uptake rates, however, were in general lower than the other $\mathrm{N}$ transforming processes $(<0.2$ umol $\left.\mathrm{l}^{-1} \mathrm{~h}^{-1}\right)$.

\section{Nitrogen budget}

Daily $\mathrm{NH}_{4}{ }^{+}, \mathrm{NO}_{3}{ }^{-}$and $\operatorname{orgN}$ (DON+PON) inputs and outputs are presented in Fig. 4. Highest nitrogen inputs are recorded for the winter period $\left(205 \mathrm{tN} \mathrm{d}^{-1}\right.$ in January) and there is a decrease towards October, concomitant with the decrease of river discharge. Upstream retention of the high $\mathrm{N}$ loads received in the Scheldt watershed is inversely linked to water discharge and directly linked to temperature (Billen et al. 2005). Thus, in winter, upstream retention is lower, and larger amounts are exported to the estuary while the opposite is observed in summer. Most of the nitrogen coming in the estuary is in the form of $\mathrm{NO}_{3}{ }^{-}$(between 43 and $57 \%$ of total $\mathrm{N}$ inputs), followed closely by orgN (between 25 and $43 \%$, mostly as DON) and finally $\mathrm{NH}_{4}{ }^{+}$(between 14 and $22 \%$ ). The agglomeration of Antwerp is an important additional $\mathrm{NH}_{4}{ }^{+}$source for the estuary (20 to $60 \%$ of total $\mathrm{NH}_{4}{ }^{+}$inputs) while canals are important additional $\mathrm{NO}_{3}{ }^{-}$sources (20 to $30 \%$ of total $\mathrm{NO}_{3}{ }^{-}$inputs). Lateral orgN sources were generally of a more limited importance (less than $10 \%$ of the total orgN inputs).

Total $\mathrm{N}$ outputs vary between 39 and $131 \mathrm{tN} \mathrm{d}^{-1}$ and are mostly in the form of $\mathrm{NO}_{3}{ }^{-}$(86 to $90 \%$ ). $\mathrm{NH}_{4}{ }^{+}$ and $\operatorname{orgN}$ almost totally disappear showing the importance of ammonification and nitrification pro- 


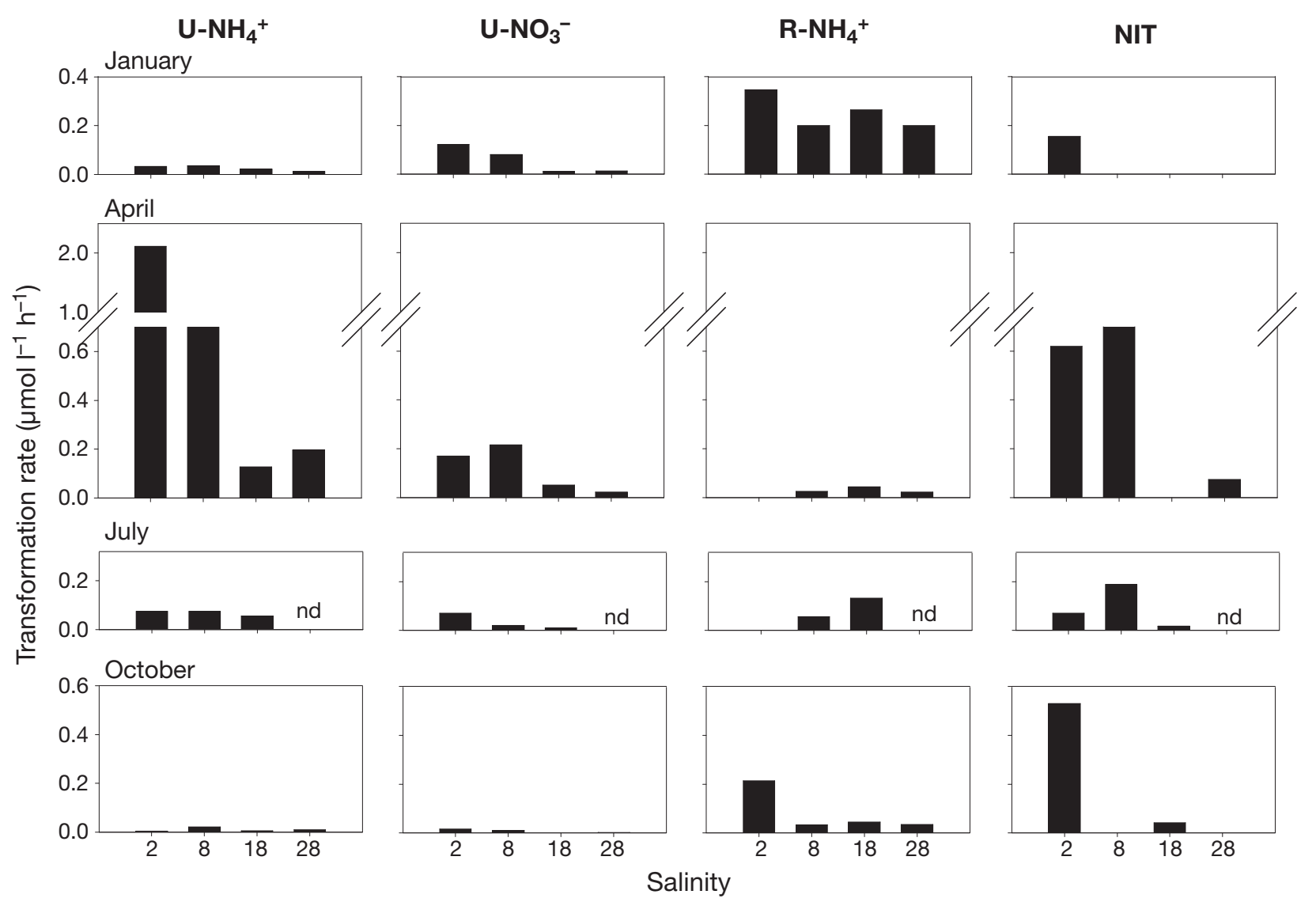

Fig. 3. Pelagic $\mathrm{N}$ transformation rates at the 4 salinity stations in the Scheldt estuary: ammonium and nitrate uptake $\left(\mathrm{U}_{-} \mathrm{NH}_{4}{ }^{+}\right.$ and $\mathrm{U}-\mathrm{NO}_{3}{ }^{-}$), ammonification ( $\mathrm{R}-\mathrm{NH}_{4}{ }^{+}$) and nitrification (NIT). nd: not done

cesses. Moreover, there is a small net production of $\mathrm{NO}_{3}{ }^{-}$(Fig. 4) indicating that nitrification (in the water column and sediments) outbalances $\mathrm{NO}_{3}^{-}$sinks (uptake by microorganisms and denitrification). Overall, there is a net retention of total fixed nitrogen in January $(37 \%)$, April (25\%), July (33\%) and October $(33 \%)$.

\section{DISCUSSION}

\section{Pelagic $\mathbf{N}$ transformation rates}

Pelagic nitrogen transformation processes (Fig. 3) showed the relative importance of $\mathrm{NH}_{4}^{+}$and $\mathrm{NO}_{3}{ }^{-}$ uptake, nitrification and ammonification for different seasons and at different locations of the estuary. Many studies report information about N-transformation process rates for different locations of the Scheldt estuary, mostly in the surface water column. Pelagic nitrification was studied by de Bie et al. (2002) using ${ }^{14} \mathrm{C}$ incubation techniques and by Andersson et al. (2006a) using ${ }^{15} \mathrm{~N}$ and ${ }^{14} \mathrm{C}$ incubation techniques. Our results on nitrification rates were in accordance with both studies, reporting the highest rates in the oligohaline part of the estuary. DIN uptake was studied by Middelburg \& Nieuwenhuize (2000), and more recently by Andersson et al. (2006b). Our measured uptake rates of $\mathrm{NH}_{4}{ }^{+}$are maximal in spring in the oligohaline zone with much lower $\mathrm{NO}_{3}{ }^{-}$uptake rates confirming the relative preference of microorganisms for $\mathrm{NH}_{4}^{+}$(Middelburg \& Nieuwenhuize 2000). $\mathrm{NH}_{4}{ }^{+}$uptake in the Scheldt estuary can be done by both phytoplankton and bacteria (Middelburg \& Nieuwenhuize 2000). As was shown by Dijkman \& Kromkamp (2006), in spring, both bacterial and phytoplankton biomass are high in the lowest salinity region of the Scheldt estuary and there are high amounts of $\mathrm{NH}_{4}{ }^{+}$available. More downstream, uptake rates decrease, probably as a result of decreasing $\mathrm{NH}_{4}{ }^{+}$and $\mathrm{NO}_{3}{ }^{-}$concentrations as observed by Middelburg \& Nieuwenhuize (2000). Ammonification rates have never been measured directly in the Scheldt estuary, but the short $\mathrm{NH}_{4}{ }^{+}$and PON turnover times reported by Middelburg \& Nieuwenhuize (2000), compared to the water residence time, imply that $\mathrm{NH}_{4}{ }^{+}$ is efficiently recycled within the estuary. Accordingly, measured $\mathrm{NH}_{4}{ }^{+}$regeneration rates largely exceeded the other processes especially during winter and fall periods. 

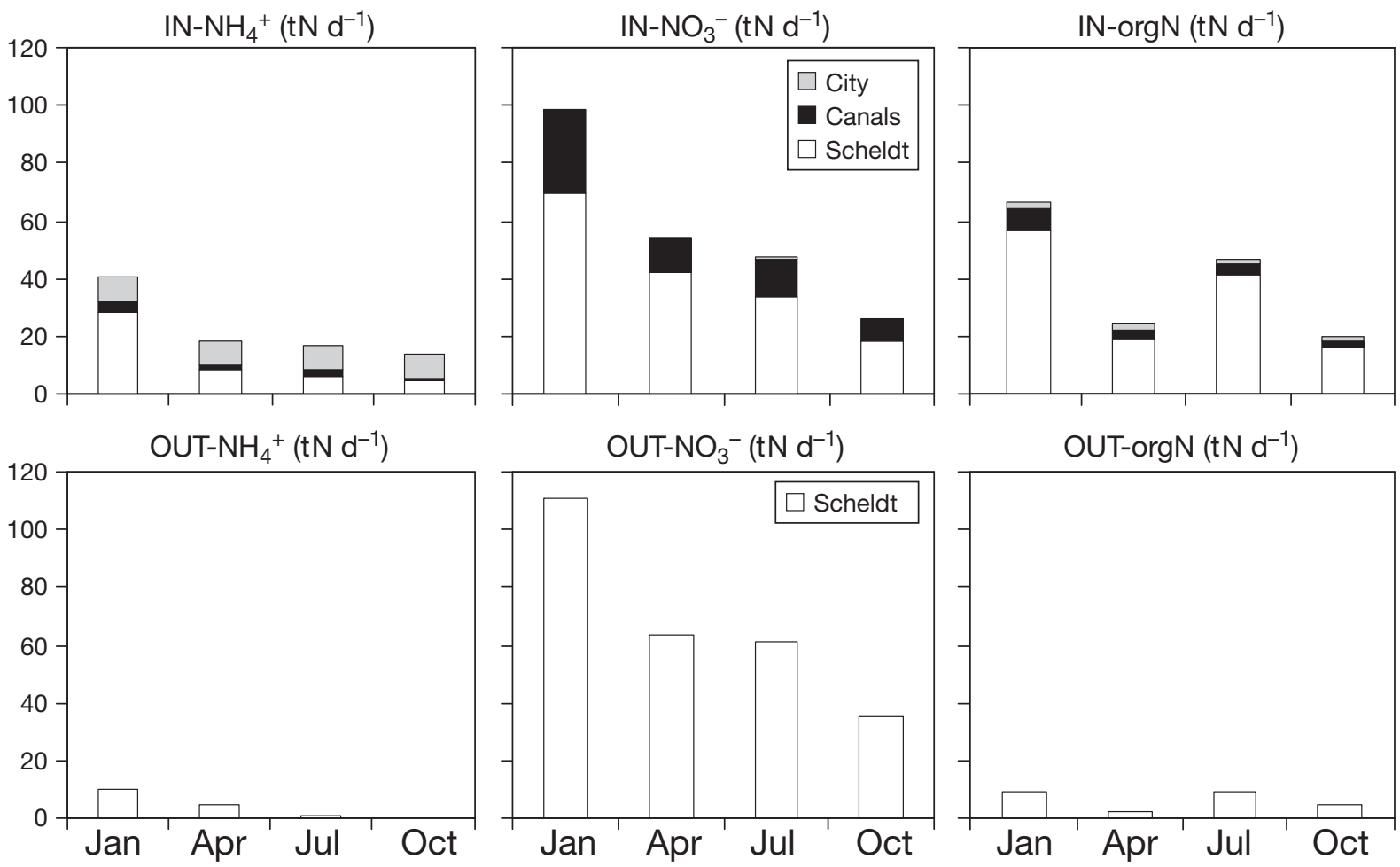

Fig. 4. Daily ammonium $\left(\mathrm{NH}_{4}^{+}\right)$, nitrate + nitrite $\left(\mathrm{NO}_{3}^{-}\right)$and organic $\mathrm{N}$ (orgN) inputs (IN-) and outputs (OUT-) for the Scheldt estuary

\section{Estuarine nitrogen transformation and removal processes}

From the general nitrogen budget in the Scheldt estuary we have seen that nitrogen arrives as $\mathrm{NO}_{3}^{-}$, orgN and $\mathrm{NH}_{4}{ }^{+}$and leaves the system mainly as $\mathrm{NO}_{3}{ }^{-}$ with a general loss of total nitrogen of 25 to $37 \%$ of the inputs. We can compare this net whole ecosystem $\mathrm{N}$ budget to our pelagic process measurements by estimating the daily $\mathrm{N}$ transformation fluxes due to pelagic ammonification, $\mathrm{NH}_{4}{ }^{+}$and $\mathrm{NO}_{3}{ }^{-}$uptake and nitrification.

To this end we assume that ammonification rates are independent of the light intensity and are constant over the whole water column, and over a $24 \mathrm{~h}$ period. Nitrification, $\mathrm{NH}_{4}{ }^{+}$uptake and $\mathrm{NO}_{3}{ }^{-}$uptake rates are all light dependent with median ratios between dark and light rates (D/L) in the Scheldt estuary equal to 0.45 for $\mathrm{NH}_{4}{ }^{+}$uptake, 0.51 for $\mathrm{NO}_{3}{ }^{-}$uptake (Middelburg \& Nieuwenhuize 2000) and 2.3 for nitrification (Andersson et al. 2006a). Measured nitrification and uptake rates were used in the photic layer of the estuary (0.4 to $2 \mathrm{~m}, \mathrm{~J}$. P. Vanderborght pers. comm.) for the daylight period (8.5 to $16 \mathrm{~h}$ ), while for the dark layer and night period, the reported D/L factors were applied to our measured rates. $\mathrm{N}$ transformation fluxes were then calculated using the rates and the volume of water. Rates measured at 4 fixed salinities (Fig. 3) were extrapolated linearly with salinity and related to the distance. The $92 \mathrm{~km}$ long estuary was divided in 920 boxes of $100 \mathrm{~m}$ in length with a known cross-sectional area (taken from Soetaert et al. 2006) and, in each of the boxes, daily $\mathrm{N}$ transformation fluxes were calculated by multiplying the corresponding rates with the corresponding volumes and cumulated for the whole estuary (Table 1).

With the in- and outputs and measured pelagic transformation processes we can establish a mass balance for each of the $\mathrm{N}$ pools $\left(\mathrm{NH}_{4}{ }^{+}, \mathrm{NO}_{3}{ }^{-}\right.$and $\left.\operatorname{orgN}\right)$ considering that the system is at steady state (sum of all inputs and sources $=$ sum of all outputs and sinks) and introducing exchange fluxes with a 'black box' compartment to balance the measured fluxes. This black box represents all estuarine compartments able to

Table 1. Daily $\mathrm{N}$ fluxes (rounded to $5 \mathrm{tN} \mathrm{d}^{-1}$ ) associated with $\mathrm{NH}_{4}{ }^{+}$and $\mathrm{NO}_{3}{ }^{-}$uptake (U-), ammonification $\left(\mathrm{R}^{-} \mathrm{NH}_{4}{ }^{+}\right.$) and nitrification (NIT) in the Scheldt estuary between Rupelmonde and Breskens

\begin{tabular}{|lrrrr|}
\hline Month & $\mathrm{U}_{-} \mathrm{NH}_{4}{ }^{+}$ & $\mathrm{U}_{-} \mathrm{NO}_{3}{ }^{-}$ & $\mathrm{R}^{-\mathrm{NH}_{4}}{ }^{+}$ & $\mathrm{NIT}$ \\
\hline January & 10 & 20 & 215 & 30 \\
April & 165 & 30 & 25 & 150 \\
July & 15 & 5 & 140 & 20 \\
October & 10 & 0 & 40 & 40 \\
\hline
\end{tabular}



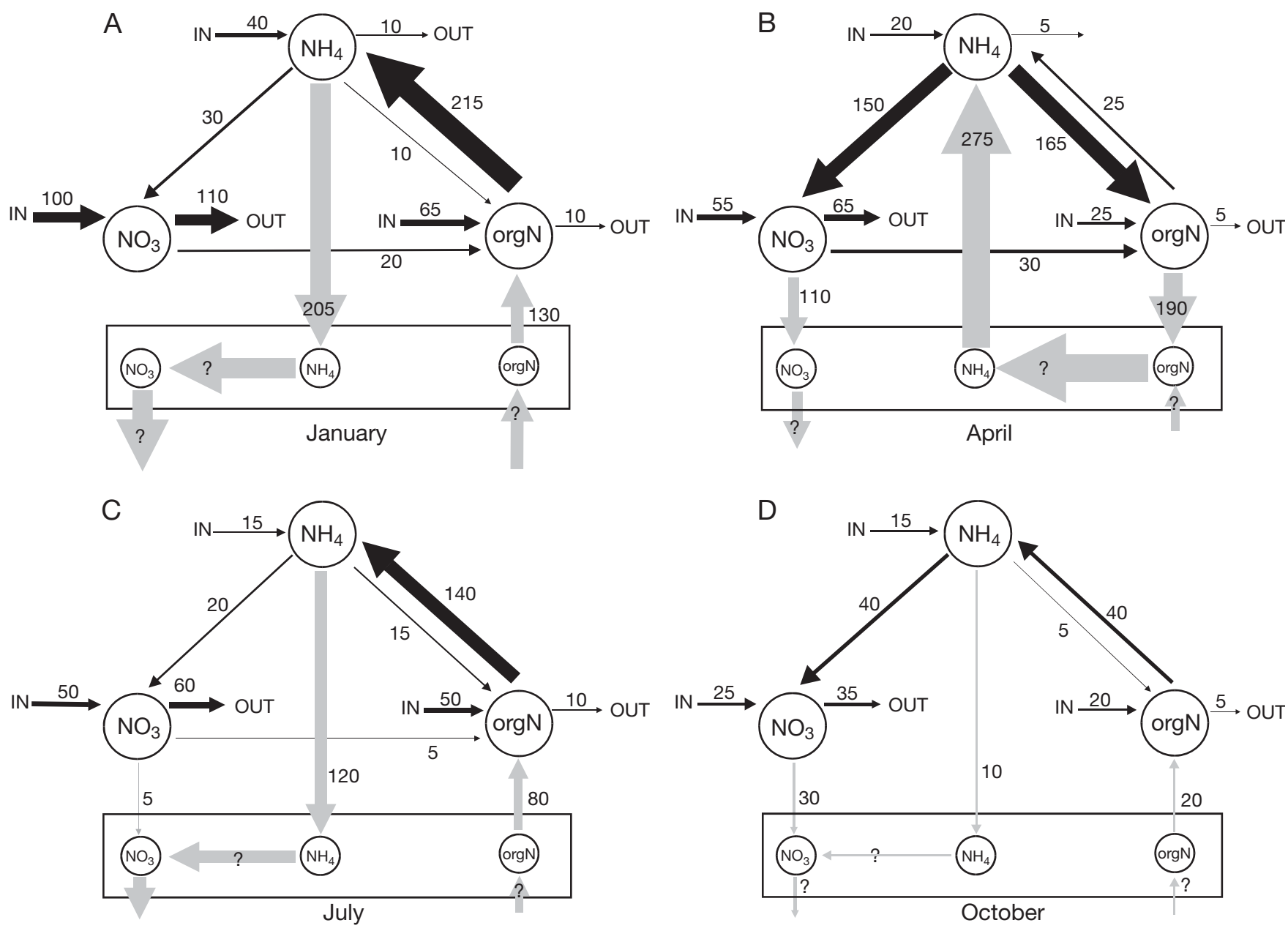

Fig. 5. N mass balance for the Scheldt estuary in January, April, July and October 2003. Fluxes in $\mathrm{tN} \mathrm{d}^{-1}$ (rounded to 5). Black arrows: measured fluxes; grey arrows: calculated fluxes by closing the mass balance. Widths of arrows are proportional to the flux. IN: inputs from the river and lateral effluents; OUT: to the North Sea. The box at the bottom represents all possible estuarine compartments that can exchange $\mathrm{N}$ with the pelagic environment: sediments, SPM rich bottom waters and intertidal areas. (?): hypothetic transformation pathways

exchange $\mathrm{N}$ with the pelagic system like the sediments, the deeper water column and intertidal areas (including marshes).

A clear contrast appears between the $\mathrm{N}$ cycling in summer, fall and winter (Fig. 5A,C,D) and that in spring (Fig. 5B). For summer, fall and winter (Fig. 5A,C,D), pelagic ammonification transforms large amounts of $\operatorname{orgN}$ to $\mathrm{NH}_{4}{ }^{+}$(40 to $215 \mathrm{tN} \mathrm{d}^{-1}$ ), representing the most important pelagic transformation pathway inside the $\mathrm{N}$ pool. However, this is not balanced by orgN inputs from upstream (20 to $\left.65 \mathrm{tN} \mathrm{d}^{-1}\right)$ or in situ production by DIN assimilation (5 to $30 \mathrm{tN} \mathrm{d}^{-1}$ ), therefore an additional $\operatorname{orgN}$ source is needed. This source is largest in January $\left(130 \mathrm{tN} \mathrm{d}^{-1}\right)$ and lowest in October $\left(20 \mathrm{tN} \mathrm{d}^{-1}\right)$. In the studied system, this source can be linked to the input of PON from the deep water layers of the river upstream, not quantified in our N-budget (see 'Materials and methods'), and to resuspension of sediments
(Chen et al. 2005). Besides being a source of PON, resuspension can also bring amino acids to the water by desorption from sediments (Fitzsimons et al. 2006). Ammonification represents the largest source for the $\mathrm{NH}_{4}{ }^{+}$pool (70 to $90 \%$ of the total $\mathrm{NH}_{4}{ }^{+}$inputs and sources). Nitrification and $\mathrm{NH}_{4}{ }^{+}$uptake remove between $15 \%$ (January) and $80 \%$ (October) of the total $\mathrm{NH}_{4}{ }^{+}$inputs and sources. An additional external $\mathrm{NH}_{4}{ }^{+}$sink is thus needed to maintain the balance (10 to $205 \mathrm{tN} \mathrm{d}^{-1}, 6$ to 7 times higher than the measured pelagic nitrification, Fig. 5). Nitrifying bacteria are often attached to particulate material (e.g. Brion et al. 2000) and nitrification occurring inside the SPM-rich bottom water layers of the Scheldt could explain this missing sink. Our unpublished nitrification rates measured for the bottom water of the Scheldt show that these exceed surface nitrification by a factor of 2 to 70 and can thus largely explain our missing sink. 
Sediment surface layers have also been recognized as sites of intense nitrification (Gribsholt et al. 2005). Another possibility is the transfer of $\mathrm{NH}_{4}{ }^{+}$to the PON pool in the SPM-rich bottom waters, either by assimilation by microorganisms (primarily bacteria as there is no light in the bottom waters) or even by adsorption, but very few studies document vertical variations in estuarine $\mathrm{N}$ transformation rates. Rosser \& Thompson (2001) reported lower $\mathrm{NH}_{4}^{+}$uptake rates in bottom than in surface waters for a shallow Australian estuary. Recently, an intertidal area from the Scheldt estuary was proven to be a sink for $\mathrm{NH}_{4}{ }^{+}$(e.g. Gribscholt et al. 2006) with 30 to $200 \mu \mathrm{mol} \mathrm{m} \mathrm{m}^{-2} \mathrm{~h}^{-1}$ retained in the vegetation and 250 to $600 \mu \mathrm{mol} \mathrm{m} \mathrm{m}^{-2} \mathrm{~h}^{-1}$ lost by coupled nitrification-denitrification. Extrapolated over the entire intertidal area $\left(67.25 \mathrm{~km}^{2}\right)$ of the estuary this would result in a $\mathrm{NH}_{4}{ }^{+}$sink of 8 to $25 \mathrm{tN} \mathrm{d}{ }^{-1}$ - much lower than our missing $\mathrm{NH}_{4}{ }^{+}$sink. Finally, anammox occurring in anoxic areas of the Scheldt could potentially also play a role but the quantitative importance of this process has never been investigated. For $\mathrm{NO}_{3}{ }^{-}$, nitrification is an important additional source (20 to $55 \%$ of the total $\mathrm{NO}_{3}{ }^{-}$inputs and sources). Export to the sea and uptake almost balance these inputs and sources, however, a small additional $\mathrm{NO}_{3}{ }^{-}$sink is needed to close the mass balance in July and October (5 to $30 \mathrm{tN}$ $\mathrm{d}^{-1}$ ). Nitrate and nitrite can be consumed in sediments by anoxic processes as denitrification, dissimilatory nitrate reduction and even anammox. Very few studies report sediment water exchange of nitrate in the Scheldt and all were made on intertidal mudflats, which may not be representative of the entire estuarine bottom. In 1995, Middelburg et al. found that sediments from intertidal mudflats were a sink of $\mathrm{NO}_{3}{ }^{-}$of $0.5 \mathrm{~mol} \mathrm{~m}^{-2} \mathrm{yr}^{-1}$, while a more recent study by Andersson (2007) reported a sink between 7 and $34 \mathrm{mmol} \mathrm{m}^{-2}$ $\mathrm{d}^{-1}$. Extrapolated over the entire bottom area of the Scheldt estuary $\left(269 \mathrm{~km}^{2}\right.$, Middelburg \& Nieuwenhuize 2000), this could represent a daily $\mathrm{NO}_{3}{ }^{-}$sink of 5 to $126 \mathrm{tN} \mathrm{d}^{-1}$. In theory, these rates largely explain our observed $\mathrm{NO}_{3}{ }^{-}$sink, even when considering that our missing $\mathrm{NH}_{4}{ }^{+}$sink is due to nitrification. However, it is clear that representative measurements of sedimentwater exchanges of nutrients in the Scheldt are missing a robust interpretation.

In spring, the situation is clearly different (Fig. 5B): the transfer of $\mathrm{N}$ from the $\mathrm{NH}_{4}{ }^{+}$pool to the orgN pool (165 tN $\mathrm{d}^{-1}$ ) dominates, reflecting a period of intense microbial growth. $\mathrm{NH}_{4}{ }^{+}$and $\mathrm{NO}_{3}{ }^{-}$uptake represent $90 \%$ of the total orgN inputs and sources. A small part of this orgN is mineralized in the water column $\left(25 \mathrm{tN} \mathrm{d}^{-1}\right)$ and an additional sink of $190 \mathrm{tN} \mathrm{d}^{-1}$ is needed to maintain the balance. This sink is likely linked to the settling of biomass to sediments. Nitrification $\left(150 \mathrm{tN} \mathrm{d}^{-1}\right)$ is of similar importance as $\mathrm{NH}_{4}{ }^{+}$uptake. There is a very efficient consumption of $\mathrm{NH}_{4}{ }^{+}$in the water column $\left(315 \mathrm{tN} \mathrm{d}^{-1}\right)$ which is not compensated by the $\mathrm{NH}_{4}{ }^{+}$brought by the river and lateral inputs nor by pelagic ammonification. An additional $\mathrm{NH}_{4}{ }^{+}$source $\left(275 \mathrm{tN} \mathrm{d}^{-1}\right)$, very similar in size to the $\operatorname{orgN} \operatorname{sink}$, is thus needed to maintain the balance. This might indicate that settled biomass is readily mineralized in the sediments and that sediment regeneration accounts for this additional $\mathrm{NH}_{4}{ }^{+}$source. For $\mathrm{NO}_{3}{ }^{-}$, nitrification is the most important source $(75 \%$ of total inputs and sources). Export to the sea and uptake cannot balance these inputs and sources and an additional $\mathrm{NO}_{3}^{-}$sink (probably by sedimentary processes as discussed above) is needed to close the mass balance $\left(110 \mathrm{tN} \mathrm{d}^{-1}\right)$.

In summer, fall and winter, the Scheldt estuary is characterized by high pelagic mineralization rates of allochthonous organic matter, largely exceeding in situ production of orgN by microorganisms. In contrast, in spring there is a very efficient transfer from the DIN pool to the orgN pool, most markedly in the upstream section of the estuary (see $\mathrm{NH}_{4}{ }^{+}$uptake rates in Fig. 3). As was shown by Dijkman \& Krompkamp (2006), at that period, both bacterial and phytoplankton biomass are high in the lowest salinity region of the Scheldt estuary, and there are high amounts of $\mathrm{NH}_{4}{ }^{+}$available. However, the produced PON pool is very rapidly recycled, probably after sedimentation of the biomass, in the deeper water layers and in the sediments.

Gazeau et al. (2005) studied the net autotrophicheterotrophic status of the Scheldt estuary for the same period of observation as in the present study based on planktonic net community production measurements. For January, July and October, they concluded that the estuarine system varied overall from net heterotrophic around a salinity of 2 to balanced or slightly autotrophic at the mouth of the estuary. The most heterotrophic situation was reported for October and the least for July. Unfortunately, no estimates were available for April, but values given for March and May indicate a situation close to balance (respiration $=$ production). Overall, Gazeau et al. (2005) showed that the pelagic system is net heterotrophic in January, July and May, consistent with our findings showing the dominance of pelagic orgN mineralization processes compared to uptake rates. The present study found that pelagic uptake rates dominate the mineralization processes in April, although the large missing $\mathrm{NH}_{4}{ }^{+}$ source indicates that mineralization occurred deeper in the water column or in the sediments.

\section{Nitrogen recycling efficiencies}

Traditional biogeochemical approaches are based on nitrogen distributions within estuaries and these 
are interpreted in terms of conservative versus nonconservative mixing. Natural abundance stable isotope studies (e.g. Kuuppo et al. 2006), deliberate in situ stable isotope labeling studies (e.g. Mulholland et al. 2004), in-stream nitrogen enrichment studies (e.g. Payn et al. 2005) and nitrogen transformation studies (e.g. Torres-Valdes \& Purdie 2006) have shown that traditional biogeochemical approaches have their limits because nitrogen molecules may be recycled many times between entering and leaving the estuary. Our combined nitrogen budget and nitrogen transformation study allows us to estimate the cycling efficiency for the 3 forms of nitrogen distinguished in this study, and hence, estimate the number of cycles undergone.

Nutrients entering an ecosystem (by import and in situ production) undergo a chain of transformation processes resulting in recycling (from the original pool, back to the original pool), elimination (from the original pool to an unreactive pool — for example nitrogen gas) or export (from the original pool to outside the system, i.e. the sea). In this context, the cycling efficiency $(E)$ is defined as the fraction of nutrients entering a system (by external and internal processes) that are recycled back to their original pool. A cycling efficiency may vary between 0 (no recycling, all entering $\mathrm{NH}_{4}{ }^{+} / \mathrm{NO}_{3}{ }^{-} /$orgN exported or eliminated) to 1 (all entering $\mathrm{NH}_{4}{ }^{+} / \mathrm{NO}_{3}{ }^{-}$/orgN reused and recycled) and values between 0.5 and 1 indicate active recycling in the estuary. Additionally, the number of times a molecule of $\mathrm{NH}_{4}{ }^{+}, \mathrm{NO}_{3}{ }^{-}$and orgN is recycled in the estuary before being exported to the sea can be obtained by $E /(1-E)$ or in other words, the ratio between the recycled fraction and the lost fraction.

Considering our results, the cycling efficiency of $\mathrm{NH}_{4}{ }^{+}, \mathrm{NO}_{3}{ }^{-}$and orgN in the whole Scheldt estuary can be estimated from the fluxes given in Fig. 5. Since several missing source and sink fluxes were not identified in this study, the recycling and loss fluxes only apply under given assumptions and inferences as discussed above: (1) for winter, summer and fall, the missing $\mathrm{NH}_{4}{ }^{+}$sink is attributed to coupled nitrification-denitrification occurring in the bottom waters and sediments and the missing orgN source is the result of an external input of material produced outside the studied zone; (2) for spring, the missing orgN sink and $\mathrm{NH}_{4}{ }^{+}$source are due to the sedimentation and mineralization of microbial biomass in the bottom waters and/or sediments. The missing $\mathrm{NH}_{4}{ }^{+}$source is thus attributed to the recycling of in situ produced orgN.

Under these assumptions and inferences, $E$ was calculated for $\mathrm{NH}_{4}{ }^{+}\left(E_{\mathrm{NH} 4}\right), \mathrm{NO}_{3}{ }^{-}\left(E_{\mathrm{NO} 3}\right)$ and orgN $\left(E_{\text {orgN }}\right)$. For $\mathrm{NH}_{4}^{+}$, in situ regeneration in the water column (as measured in January, July and October) and/or sediments (as deduced from the missing $\mathrm{NH}_{4}{ }^{+}$ source in April) largely exceeded uptake of DIN. Part of the $\mathrm{NH}_{4}{ }^{+}$produced from mineralization processes is thus based on the degradation of allochthonous organic material and should thus be regarded as an external source of $\mathrm{NH}_{4}{ }^{+}$and not a recycled source. The recycling of $\mathrm{NH}_{4}{ }^{+}$is thus given by the DIN uptake flux and $E_{\mathrm{NH} 4}$ can be calculated as the ratio of DIN uptake over all $\mathrm{NH}_{4}{ }^{+}$inputs and sources. For $\mathrm{NO}_{3}{ }^{-}$, in situ regeneration (nitrification) exceeds $\mathrm{NO}_{3}{ }^{-}$uptake. Part of the $\mathrm{NO}_{3}^{-}$produced from nitrification is thus based on the oxidation of allochthonous ammonium and should thus be regarded as an external source of $\mathrm{NO}_{3}{ }^{-}$and not a recycled source. $\mathrm{NO}_{3}{ }^{-}$recycling is thus given by the $\mathrm{NO}_{3}{ }^{-}$uptake flux and $E_{\mathrm{NO} 3}$ can be calculated as the ratio of $\mathrm{NO}_{3}{ }^{-}$uptake over all $\mathrm{NO}_{3}{ }^{-}$inputs and sources. For $\operatorname{orgN}$, in situ regeneration by DIN uptake was lower than mineralization. The recycling of $\operatorname{org} N$ is thus given by the DIN uptake flux and $E_{\text {orgN }}$ can be calculated as the ratio of DIN uptake over all orgN inputs and sources. Below, we will briefly discuss what happens with $E$ when we choose other assumptions.

For $\mathrm{NH}_{4}^{+}$(Table 2), we saw that in winter, summer and fall, only a small fraction of the incoming flux was recycled within the water column of the estuary, and $E$ is around $10 \%$ (9 to $13 \%$ ). Most of the $\mathrm{NH}_{4}{ }^{+}$was actually removed from the system probably through the combined processes of nitrification-denitrification occurring in the bottom waters and sediments as discussed previously. In these cases the number of cycles undergone by one $\mathrm{NH}_{4}{ }^{+}$molecule is between 0.1 and 0.15 and recycling is thus of very limited importance. The spring situation was clearly different with a cycling efficiency of $61 \%$ and the number of cycles undergone by one $\mathrm{NH}_{4}{ }^{+}$molecule being 1.6. $\mathrm{NH}_{4}{ }^{+}$is

Table 2. Cycling efficiency $(E)$ and number of cycles (n) undergone for $\mathrm{NH}_{4}{ }^{+}, \mathrm{NO}_{3}{ }^{-}$and orgN in the Scheldt estuary. For winter, summer and fall, under the assumptions explained in the text

\begin{tabular}{|c|c|c|c|c|}
\hline & Winter & Spring & Summer & Fall \\
\hline \multicolumn{5}{|l|}{$\mathrm{NH}_{4}^{+}$} \\
\hline Recycled $\left(\mathrm{tN} \mathrm{d}^{-1}\right)$ & 30 & 195 & 20 & 5 \\
\hline Total IN $\left(\mathrm{tN} \mathrm{d}^{-1}\right)$ & 255 & 320 & 155 & 55 \\
\hline$E_{\mathrm{NH} 4}$ & 0.12 & 0.61 & 0.13 & 0.09 \\
\hline $\mathrm{n}_{\mathrm{NH} 4}$ & 0.13 & 1.56 & 0.15 & 0.10 \\
\hline \multicolumn{5}{|l|}{$\mathrm{NO}_{3}^{-}$} \\
\hline Recycled $\left(\mathrm{tN} \mathrm{d}^{-1}\right)$ & 20 & 30 & 5 & 0 \\
\hline Total IN $\left(\mathrm{tN} \mathrm{d}^{-1}\right)$ & 130 & 205 & 70 & 65 \\
\hline$E_{\mathrm{NO} 3}$ & 0.15 & 0.15 & 0.07 & 0.00 \\
\hline $\mathrm{n}_{\mathrm{NO} 3}$ & 0.18 & 0.17 & 0.08 & 0.00 \\
\hline \multicolumn{5}{|l|}{$\operatorname{orgN}$} \\
\hline Recycled $\left(\mathrm{tN} \mathrm{d}^{-1}\right)$ & 30 & 195 & 20 & 5 \\
\hline Total IN $\left(\mathrm{tN} \mathrm{d}^{-1}\right)$ & 225 & 220 & 150 & 45 \\
\hline$E_{\text {orgN }}$ & 0.13 & 0.89 & 0.13 & 0.11 \\
\hline $\mathrm{n}_{\text {orgN }}$ & 0.15 & 7.80 & 0.15 & 0.13 \\
\hline
\end{tabular}


actively taken up and regenerated in the estuarine water column and probably sediments.

For $\mathrm{NO}_{3}^{-}$(Table 2), the cycling efficiency decreases from $15 \%$ in winter to $0 \%$ in fall and shows again that most of $\mathrm{NO}_{3}^{-}$produced in this system is not recycled (number of cycles are 0 to 0.18 ) but lost as export to the North Sea (winter and summer) and probably as denitrification in the sediments (spring and fall).

Finally, for orgN (Table 2), in winter, summer and fall, $E$ varies between 11 and $13 \%$ with a low number of cycles (0.13 to 0.15). Recycling is thus of very limited importance, mostly because of the very low DIN uptake rates, and $\operatorname{orgN}$ is thus mostly lost and probably exported after mineralization-nitrificationdenitrification in sediments. As for $\mathrm{NH}_{4}{ }^{+}$, the spring situation was clearly different with a very efficient recycling ( $E$ close to $90 \%$ ) and each orgN atom recycled 7.8 times.

We can also estimate $E$ in case our inferences about sources and sinks do not hold. For winter, summer and fall, if the $\mathrm{NH}_{4}{ }^{+}$sink and orgN sources are linked to an in situ production of biomass in an unaccounted estuarine compartment, then, the recycling efficiencies increase to around $60 \%$ for $\mathrm{NH}_{4}{ }^{+}$and to around $70 \%$ for $\operatorname{orgN}$, but stay rather low in fall $(\sim 30 \%$ for both $\mathrm{NH}_{4}{ }^{+}$and $\operatorname{orgN}$ ).

The Scheldt estuary is a turbid, nutrient-rich, macrotidal system, with low autochthonous production (because of the high turbidity) and high allochthonous organic matter inputs. The ecosystem is net heterotrophic during most of the year and in a balanced condition in spring (Gazeau et al. 2005). This has large consequences on the $\mathrm{N}$ recycling efficiency. We have shown that although large amounts of inorganic $\mathrm{N}$ nutrients are generated in the system by mineralization of organic matter, these are not reused but rather eliminated and exported to the sea. This was previously reported for other turbid estuaries (including the Scheldt) by Heip et al. (1995), who reported that 'because of light limitation, any nutrient produced by the mineralization of allochthonous material remains unused and does not contribute to autochthonous production'. Recycling efficiencies for inorganic $\mathrm{N}$ are thus low throughout most of the year. High primary production in the most upstream part of the estuary balances the high mineralization fluxes only in the spring, and recycling efficiencies increase for $\mathrm{NH}_{4}{ }^{+}$ and $\operatorname{org} \mathrm{N}$.

For non-turbid temperate tidal estuaries which are not light limited, Heip et al. (1995) estimated the potential recycling efficiency using total system production-respiration estimates and reported an acrosssystem, long-term average efficiency of 70 to $80 \%$, similar to that calculated in the present study for $\mathrm{NH}_{4}{ }^{+}$ and $\operatorname{org} \mathrm{N}$ in the spring. In this case inorganic $\mathrm{N}$ recy- cling and uptake are closely coupled and recycling efficiencies increase.

In river networks, the number of spirals, comparable to cycling numbers, are generally calculated as the ratio between the length of the stream and the 'average distance traveled by a nutrient molecule in inorganic phase prior to uptake' ( $S w$ ) (Ensign \& Doyle 2006). It thus considers a close coupling between uptake and regeneration processes. For a hypothetical river network with increasing stream orders (Ensign \& Doyle 2006), spiraling numbers for $\mathrm{NH}_{4}{ }^{+}$increase slowly in streams from orders 1 to 4 , mainly because of increasing stream length and rather constant $S w$, but decrease strongly in order 5 streams because of a very large increase in the $\mathrm{Sw}$. $\mathrm{NO}_{3}{ }^{-}$spiraling numbers increase from order 1 to order 5 streams, mostly because of increasing streamlength and decreasing $S w$. Reported spiraling numbers for 5th order rivers (like the Scheldt) are around 10 for $\mathrm{NH}_{4}{ }^{+}$, and around 100 for $\mathrm{NO}_{3}{ }^{-}$. These values are much higher than our recycling times, but Ensign \& Doyle (2006) emphasize that the absolute values of cycling numbers should be considered with care as they are highly dependent on the watershed geomorphology (stream length, water depth, current velocity, etc.).

\section{CONCLUSIONS}

Nitrogen transformation and recycling in a temperate macrotidal turbid estuary such as the Scheldt are dominated by the mineralization of organic matter (OM) for all seasons. The large supply of DIN from pelagic and benthic OM mineralization exceeds inputs from river and lateral influents and in all seasons except in spring, only a small fraction (around 10\%) is reused by microorganisms. Most of the incoming and produced DIN is thus eliminated (between 50 and $60 \%$ ) probably by anoxic reduction processes in the sediments while the remaining (30 to $40 \%$ ) is exported. Overall, the estuary has a very low recycling efficiency for DIN but is a very efficient DIN filter. Only the spring situation differs significantly from this general pattern: high phytoplankton and bacterial numbers are responsible for an increased biomass production leading to the fixation of $\mathrm{NH}_{4}{ }^{+}$into $\operatorname{orgN}$. In this period, we have a larger fraction of DIN (around $70 \%$ ) that is reused by microorganisms. Overall, in spring, the estuary is thus an efficient DIN recycling reactor with a much lower filtering efficiency (only $2 \%$ of all incoming and produced DIN).

Acknowledgements. This work was carried out in the framework of a VLANEZO project (Flemish-Dutch cooperation for Sea Research) and we thank FWO (Fonds voor Wetenschappelijk Onderzoek, Flanders, Belgium) and NWO (Neder- 
landse Organisatie voor Wetenschappelijk Onderzoek, The Netherlands) for their financial support. We are also grateful to 4 anonymous reviewers for their constructive feedback.

\section{LITERATURE CITED}

Andersson MGI (2007) Nitrogen cycling in a turbid tidal estuary. PhD dissertation, University of Utrecht, The Netherlands

Andersson MGI, Brion N, Middelburg JJ (2006a) Comparison of nitrifier activity versus growth in the Scheldt estuary: a turbid, tidal estuary in northern Europe. Aquat Microb Ecol 42(2):149-158

Andersson MGI, van Rijswijk P, Middelburg JJ (2006b) Uptake of dissolved inorganic nitrogen, urea and amino acids in the Scheldt estuary: comparison of organic carbon and nitrogen uptake. Aquat Microb Ecol 44(3):303-315

Baeyens W, van Eck B, Lambert C, Wollast R, Goeyens L (1998) General description of the Scheldt estuary. Hydrobiologia 366:1-14

Billen G, Somville M, Debecker E, Servais P (1985) A nitrogen budget of the Scheldt hydrographical basin. Neth J Sea Res 19(3-4):223-230

Billen G, Garnier J, Rousseau V (2005) Nutrient fluxes and water quality in the drainage network of the Scheldt basin over the last 50 years. Hydrobiologia 540:47-67

Brion N, Billen G, Guezennec L, Ficht A (2000) Distribution of nitrifying activity in the Seine River (France) from Paris to the estuary. Estuaries 23(5):669-682

Chen MS, Wartel S, Van Eck B, Van Maldegem D (2005) Suspended matter in the Scheldt estuary. Hydrobiologia 540: 79-104

Dafner E, De Galan S, Goeyens L (1999) Microwave digestion of organic substances, a useful tool for dissolved organic nitrogen measurements. Water Res 33(2):548-554

de Bie MJM, Starink M, Boschker HTS, Peene JJ, Laanbroek HJ (2002) Nitrification in the Schelde estuary: methodological aspects and factors influencing its activity. FEMS Microbiol Ecol 42(1):99-107

Diaconu C, Brion N, Elskens M, Baeyens W (2005) Validation of a dynamic ammonium extraction technique for the determination of $\mathrm{N}-15$ at enriched abundances. Anal Chim Acta 554(1-2):113-122

Dijkman NA, Kromkamp J (2006) Phospholipid-derived fatty acids as chemotaxonomic markers for phytoplankton and application to derive phytoplankton composition in the Schelde estuary (Belgium and the Netherlands). Mar Ecol Prog Ser 324:113-125

Elskens M, Penninckx MJ, Vandeloise R, Vander Donckt E (1988) Use of a simplex technique and contour diagrams for the determination of the reaction-rate constants between glutathione and thiram in the presence of NADPH. Int J Chem Kin 20(11):837-848

Elskens M, Baeyens W, Brion N, De Galan S, Goeyens L, de Brauwere A (2005) Reliability of N flux rates estimated from ${ }^{15} \mathrm{~N}$ enrichment and dilution experiments in aquatic systems. Global Biogeochem Cycles 19:GB4028

Ensign SH, Doyle MW (2006) Nutrient spiraling in streams and river networks. J Geophys Res 111:G04009

Fitzsimons MF, Millward GE, Revitt DM, Dawit MD (2006) Desorption kinetics of ammonium and methylamines from estuarine sediments: Consequences for the cycling of nitrogen. Mar Chem 101(1-2):12-26

Gazeau F, Gattuso JP, Middelburg JJ, Brion N, Schiettecatte LS, Frankignoulle M, Borges AV (2005) Planktonic and whole system metabolism in a nutrient-rich estuary (The
Scheldt Estuary). Estuaries 28(6):868-883

Gribsholt B, Boschker HTS, Struyf E, Andersson M and others (2005) Nitrogen processing in a tidal freshwater marsh: a whole ecosystem ${ }^{15} \mathrm{~N}$ labeling study. Limnol Oceanogr 50: 1945-1959

Gribsholt B, Struyf E, Tramper A, Andersson MGI and others (2006) Ammonium transformation in a nitrogen-rich tidal freshwater marsh. Biogeochem 80:289-298

Heip CHR, Goosen NK, Herman PMJ, Kromkamp J, Middelburg JJ, Soetaert K (1995) Production and consumption of biological particles in temperate tidal estuaries. Oceanogr Mar Biol Annu Rev 33:1-149

Hulth S, Aller RC, Canfield DE, Dalsgaard T and others (2005) Nitrogen removal in marine environments: recent findings and future research challenges. Mar Chem 94(1-4): 125-145

Koroleff F (1969) International Council for the Exploration of the Sea (ICES), Copenhagen, Interlaboratory Report 3: $19-22$

Kromkamp J, Peene J, Vanrijswijk P, Sandee A, Goosen N (1995) Nutrients, light and primary production by phytoplankton and microphytobenthos in the eutrophic, turbid Westerschelde Estuary (the Netherlands). Hydrobiologia 311(1-3):9-19

Kuuppo P, Tamminen T, Voss M, Schulte U (2006) Nitrogenous discharges to the eastern Gulf of Finland, the Baltic Sea: elemental flows, stable isotope signatures, and their estuarine modification. J Mar Syst 63(3-4):191-208

Lipschultz F, Wofsy SC, Fox LE (1986) Nitrogen metabolism of the eutrophic Delaware River ecosystem. Limnol Oceanogr 31(4):701-716

Middelburg JJ, Nieuwenhuize J (2000) Uptake of dissolved inorganic nitrogen in turbid, tidal estuaries. Mar Ecol Prog Ser 192:79-88

Middelburg JJ, Klaver G, Nieuwenhuize J, Vlug T (1995) Carbon and nitrogen cycling in intertidal sediments near Doel, Scheldt Estuary. Hydrobiologia 311:57-69

Miller CA, Penry DL, Glibert PM (1995) The impact of trophic interactions on rates of nitrogen regeneration and grazing in Chesapeake Bay. Limnol Oceanogr 40(5):1005-1011

Mulholland PJ, Valett HM, Webster JR, Thomas SA, Cooper LW, Hamilton SK, Peterson BJ (2004) Stream denitrification and total nitrate uptake rates measured using a field N-15 tracer addition approach. Limnol Oceanogr 49(3): 809-820

Nieuwenhuize J, Maas YEM, Middelburg JJ (1994) Rapid analysis of organic carbon and nitrogen in particulate materials. Mar Chem 45:217-224

Officer CB (1979) Discussion of the behaviour of nonconservative dissolved constituents in estuaries. Estuar Coast Mar Sci 9:91-94

OSPAR Commission (2005) Data report on the comprehensive study of riverine inputs and direct discharges (RID) in 2003. Annex 1 (Belgium) and 6 (The Netherlands), OSPAR publication number 2005/249, OSPAR Commission, UK. Available at: www.ospar.org/eng/html/welcome.html

Payn RA, Webster JR, Mulholland PJ, Valett HM, Dodds WK (2005) Estimation of stream nutrient uptake from nutrient addition experiments. Limnol Oceanogr Methods 3: $174-182$

Regnier P, Steffel CI (1999) A high resolution estimate of the inorganic nitrogen flux from the Scheldt estuary to the coastal North Sea during a nitrogen-limited algal bloom, spring 1995. Geochim Cosmochim Acta 63(9): 1359-1374

Rosser S, Thompson PA (2001) Phytoplankton of the SwanCanning Estuary: a comparison of nitrogen uptake by 
different bloom assemblages. Hydrol Process 15(13): 2579-2594

Seitzinger, SP, Harrison J, Bohlke J, Bouwman A and others (2006) Denitrification across landscapes and waterscapes: a synthesis. Ecol Appl 16(6):2064-2090

Servais P, Garnier J, Demarteau N, Brion N, Billen G (1999) Supply of organic matter and bacteria to aquatic ecosystems through waste water effluents. Water Res 33(16): 3521-3531

Soetaert K, Herman PMJ (1995) Nitrogen dynamics in the Westerschelde Estuary (SW Netherlands) estimated by

Editorial responsibility: Howard Browman, Storebø, Norway means of the ecosystem model MOSES. Hydrobiologia 311(1-3):225-246

Soetaert K, Middelburg JJ, Heip C, Meire P, Van Damme S, Maris T (2006) Long-term change in dissolved inorganic nutrients in the heterotrophic Scheldt estuary (Belgium, The Netherlands). Limnol Oceanogr 51(1):409-423

Strickland JDH, Parsons TR (1972) A practical handbook of seawater analysis, 2nd edn. Bull Fish Res Board Can 167

Torres-Valdes S, Purdie DA (2006) Nitrogen removal by phytoplankton uptake through a temperate non-turbid estuary. Estuar Coast Shelf Sci 70:473-486

Submitted: April 25, 2007; Accepted: September 12, 2007 Proofs received from author(s): March 20, 2008 